\title{
A new responsibility for science
}

A major impact of public reaction to the Soviet invasion of Afghanistan has been to legitimate the slowing down - and in some cases even the reversal - of efforts to limit the global spread of nuclear weapons. The most obvious manifestation of this process has been President Carter's decision to defer consideration by the US Senate of the new Strategic Arms Limitation Treaty (SALT II), concluded last year after lengthy negotiations with the USSR. But the impact of the Soviet moves is already making itself felt across a wide range of non-proliferation initiatives - and the net result can only be to bring the threat of nuclear war a step nearer.

It seems inevitable, for example, that the new strains on EastWest relations will provide one more hurdle to the successful negotiation of a comprehensive test ban, severely decreasing hopes for an early agreement. In Pakistan, US moves to cut off military and economic aid last year in an attempt to wean the country away from nuclear weapons production are now being reversed to help provide a counterweight to the Soviet presence in nearby Afghanistan. And to mollify Pakistan's own neighbour, India, State Department officials in Washington are said to be dropping their opposition to the export of highly-enriched nuclear fuels for the Tarapur nuclear plant, despite India's coniinued refusal to accept international safeguards.

To warn of the dangers inherent in these moves is in no way to condone the Soviet Union's actions, nor to deny that the USSR must share a large part of the blame for their implications. But as far as US policy is concerned, it is important that the realities of the situation are not confused with images of that reality.

The paradox of President Carter's position, for example, is that by taking a firm stand on international issues such as Iran and Afghanistan, he has regained a reputation as a political leader previously lost for failures in relatively unrelated domestic spheres, namely energy and rising inflation. Furthermore the defense industry had not been slow to point out the domestic merits of increased military spending. Pentagon officials, for example, point out that in the past defense-sponsored research has provided a major boost to civilian technologies - and that given current national concerns about declining rates of innovation, increasing the military R\&D budget could again help efforts in this direction.

The volatility of US politics tends to create a rhetoric designed primarily for domestic consumption. And in many ways the potential political gains that might have been achieved by supporting SALT have been overtaken by the gains of undercutting the same agreement.

No-one can pretend that the way forward for arms control is clear. But one strategy that could be pursued with vigour would be to separate discussions aimed at limiting nuclear weapons as far as possible from the temporarily sinking ship of détente. In the past, the scientific community has ably taken on this role, using its position on the fringes of the political establishment to keep open lines of communication that might otherwise be lost. Last week the council of the American Association for the Advancement of Science passed a resolution emphasising the continued need to support arms control efforts, and drawing attention to the particular responsibility of scientists to help this process (see page 234). We support the AAAS's efforts, and urge British scientists to do likewise.

\section{No engineers without teachers}

AT last the Finniston report on the training and status of engineers in Britain has been officially published. The history of leaks of the report has been so long that it is rather an anticlimax to have the real thing on one's desk*; Nature described the bulk of its recommendations last summer (2 August 1979, page 352). We support most of them as indicating a practical, as opposed to bigheadedly political route towards the improvement of Britain's economic competitiveness. Britain has too long neglected and rejected the applied scientist and engineer as a creator of wealth; the paradigm of economic activity has been the City, where paper rather than materials are moved: a second-order economic activity. There is a strong element of class-consciousness in this anti-technical valuation, and it pervades the whole of the establishment, including the Civil Service. Even the Department of Industry is neglectful of technological change.

Perhaps Finniston can blow a wind of change through all this but it is unlikely. A sense of depression is increased if one looks at the figures for the numbers of science teachers in training in England and Wales - for these are the people who will influence the outlook of the next generation. Take physics and chemistry, for example. Of 19,500 physics teachers in secondary schools in January 1977 , only $43 \%$ were actually qualified to teach physics. Of 18,800 chemistry teachers, half were qualified. The majority of teachers were 'filling-in', when their basic training was in another subject. In January 1979, the annual number of new physics teachers needed to fill vacancies and begin to replace unqualified teachers was estimated by the Department of Education and Science to be 1,300 . In chemistry the number was 600 .

Against this, in 1979 just 244 physics and 345 chemistry graduates entered one-year DipEd courses to learn to teach - satisfying roughly one fifth of the need for physicists and one half that for chemists.

Mathematics is worse and biology better off than this. Of 48,300 maths teachers (maths is a compulsory subject), $62 \%$ are qualified, and there is an annual need (DES figures) of 4,300. The input of graduate trainees in 1979 was 636 - one seventh the need. In biology there are 20,900 teachers of whom $55 \%$ are qualified; the annual need is 600; and the 1979 graduate input was 657, satisfying demand.

In all subjects the position is worsening. Three years previously there were 412 graduate physics entrants into teacher training ( 244 in 1979); 438 chemists ( 345 in 1979) and 800 mathematicians (636 in 1979). (Biology fell slightly from 691 in 1976 to 657 in 1979.)

Without well-qualified science teachers, there is little hope for the future of science and engineering in Britain. Now is also time to discuss how to attract good science teachers.

*'Engineering our future'. Report of the Committee of Inquiry into the engineering profession. HMSO, £5.

\section{Editor of Nature}

NATURE is pleased to announce the appointment of Mr John Maddox as Editor. Mr Maddox is presently Director of the Nuffield Foundation and was Editor of Nature from 1966 to 1973. He will take up his appointment not later than 30 June. MacMillan Journals are particularly appreciative of Nature's development during Dr Davies' editorship and it is $\mathrm{Mr}$ Maddox's intention to build on his achievements. 